\title{
Interventions on Bullying and Cyberbullying in Schools: A Systematic Review
}

\author{
Elisa Cantone ${ }^{1, *}$, Anna P. Piras ${ }^{1}$, Marcello Vellante ${ }^{1}$, Antonello Preti ${ }^{1}$, Sigrun Daníelsdóttir ${ }^{2}$, \\ Ernesto D'Aloja ${ }^{1}$, Sigita Lesinskiene ${ }^{3}$, Mathhias C. Angermeyer ${ }^{1,4}$, Mauro G. Carta ${ }^{2}$ \\ and Dinesh Bhugra ${ }^{5}$
}

\author{
${ }^{I}$ Department of Public Health and Clinical and Molecular Medicine, University of Cagliari, Italy; ${ }^{2}$ Directorate of \\ Health Barónsstíg 47, IS-105 Reykjavik, Iceland; ${ }^{3}$ Vilnius University, Clinic of Psychiatry, Faculty of Medicine, Vilnius, \\ Lithuania; ${ }^{4}$ Center for Public Mental Health, Gosim Austria; ${ }^{5}$ Institute of Psychiatry (KCL), DeCrespigny Park, \\ London, United Kingdom
}

\begin{abstract}
Background: bullying (and cyberbullying) is a widespread phenomenon among young people and it is used to describe interpersonal relationships characterized by an imbalance of power. In this relationships often show aggressive behavior and intentional "harm doing" repeated over time. The prevalence of bullying among youth has been reported to vary widely among countries (5.1\%-41.4\%) and this behavior seems generally higher among student boys than girls. Several school interventions have been developed to reduce bullying, but reported inconsistent results possibly related to limitations in the study design or to other methodological shortcomings. Aims: evaluating randomized-controlled trials (RTCs) conducted between 2000 and 2013 to assess the effectiveness of school interventions on bullying and cyberbullying. Methods: a systematic search of the scientific literature was conducted on Pubmed/Medline and Ebsco online databases. We also contacted experts in the field of preventive bullying research. Results: 17 studies met the inclusion criteria. The majority of studies did not show positive effects in the long term; the interventions focused on the whole school were more effective in reducing bullying than interventions delivered through classroom curricula or social skills training alone. Conclusion: while there is evidence that programs aimed at reducing bullying can be effective in the short term, their long-term effectiveness has not been established, and there are important differences in the results based on gender, age and socio-economic status of participants. Internal inconsistency in the findings of some studies, together with the wide variability of experimental designs and lack of common standardized measures in outcome evaluation, are important limitations in this field of research.
\end{abstract}

Keywords: Bullying, cyber bullying, randomized controlled trials, school.

\section{INTRODUCTION}

Bullying is a significant problem in schools [1]. It is defined as intentional aggressive behaviour by a single person or a group against a peer who cannot easily defend himself/herself. Its nature is repetitive over time, lasting weeks and, at times, even months or years. Bullying can take on the following forms: physical (punching or kicking, seizing or damaging other people's belongings); verbal (ridiculing, insulting, repeatedly mocking someone, making racist remarks); relational (leaving one or more peers out of aggregation groups) and indirect (spreading rumours or gossip about a student) [2].

In recent years, as a result of the widespread use of smart phones and Internet access among youth, another phenomenon has surfaced: cyberbullying. Cyberbullying is characterized by the use of electronic forms of contact (e.g., phone calls, text messages, picture/video clips, e-mails, chat rooms, instant messaging, websites) [3], that allow the perpetrator to

*Address correspondence to this author at the Department of Public Health and Clinical and Molecular Medicine, University of Cagliari, Italy; Tel: 070.6093498; E-mail: elisa.cantone@libero.it remain anonymous and intensify feelings of discomfort in the victim [4]. Cyberbullying can take on the following forms: flaming (online fights using electronic messages with angry and vulgar language); harassment (repeatedly sending mean, insulting messages); cyberstalking (repeated, intense harassment and denigration that includes threats or creates significant fear); denigration (spreading rumours online; sending or posting gossip about a person to damage his/her reputation or friendships); impersonation (pretending to be someone else and sending or posting material to get that person in trouble or danger, or damage that person's reputation or friendships); outing (sharing someone's secrets or embarrassing information or images online); trickery (tricking someone into revealing secrets or embarrassing information, then sharing it online); and exclusion (intentionally and cruelly excluding someone from an online group) [5].

Three main roles have been identified within the bullying cycle: the bully, the victim, and bystanders [6]. Usually the bully is the strongest among peers and has a strong need for power. In fact, the main purpose of bullying behaviours is to undermine the social status of the victim and his/her sense of personal security, while at the same time raising the bully's self-esteem and social status. As a consequence, bullying 
actions usually take place in front of an audience. Bystanders can support the bully, defend the victim, or serve as passive onlookers. In the majority of cases bystanders attend without intervening but still they are considered an integral part of the bullying situation. The victims are of lower status than their aggressors and tend to isolate themselves due to bullying appearing unable to defend themselves and in need of protection.

The school has been identified as a context where bullying behaviours frequently occur [1]. Sometimes persecution also occurs on the way to and from school but cyberbullying, by definition, can occur anywhere. Finally, the prevalence of victimization and bullying changes in different age groups. Dake and collaborators [7] have shown that the incidence of victimization and bullying in primary school (grades 1-5) is higher than in middle (grades 6-8) and secondary school (grades 9-12). While, as mentioned in the report of Ttofi [8], the incidence of bullying is more prevalent among males versus female.

Research also indicates that being the victim of bullying contributes independently to children's mental health problems [9]. The persistence of the phenomenon for prolonged periods of time may cause the development of low self esteem and depressive symptoms that can persist into adulthood $[2,10]$. Bullying victims have reported various forms of psychological, physical and social suffering, such as sleep disturbances, enuresis, abdominal pain, headache, selfdestructive behaviour, feeling sad, and feeling socially rejected or isolated [11-13]. They experience greater social marginalization and lower social status and the effects of the bullying experience appear to last over time [14]. In fact, along with their bullies, victims have a significantly amplified risk of anxiety, depressive symptoms and suicidal ideation than children who are not bullied or bully $[15,16]$. A recent meta-analysis [17] has confirmed the strong correlation between being bullied and psychosomatic disorders in adolescents and children. Bullies are also more frequently involved in delinquency and substance abuse than other children and adolescents. Studies in school settings reported that victims showed problems of adjustment and bonding as well as difficulties in the completion of homework, while bullies showed increased school absenteeism [18].

Thus, it seems particularly important in this context to analyse how the different variables involved in the process of victimization and bullying influence each other, and to take into account that some studies have only looked at bullying and victimization outcomes, while others have also assessed associated mental health and social outcomes. We also consider it relevant to understand how many treatments were able to reduce the principal components of bullying (bullying, victimization and bystanders behaviour).

To our knowledge, only few prior systematic reviews have been conducted on school-based interventions to reduce bullying $[19,10]$. These reviews though included several kinds of study and experimental design, making it difficult to compare and evaluate the outcomes. This work tries to avoid some of these difficulties by selecting RCT designs only. Finally, this work is part of a collection of reviews on several aspects of children's and adolescents' well-being. They concern, for example, the promotion of health and well-being in schools through focused intervention programs [20], the development of physical activity interventions within schools to support and improve general mental health [21], and the expansion of school-based programs targeting children with mental disorders [22].

Taking the above into consideration, the objective of this specific study is to systematically review the international research in this field and critically analyze the results of school-based interventions to reduce or prevent bullying and cyber-bullying.

\section{METHODOLOGY}

Bullying is of interest to researchers and clinicians as those who are bullied can develop problems later on in life, thus that public mental health perspective and interventions become important for a greater understanding of the phenomenon. The work group made a first search of all the studies available on the theme in an online medical database (PubMed/Medline) with some highly comprehensive keywords ("school", "mental health", "education context") in the time interval of 2000-2013. From over 17,000 items, and after double-blind selection on title and abstract, 1051 papers were selected concerning actions or promotion programs. Most actions focused on the promotion of general or psychological well-being, on the management of emotions or the identification of mental health needs, the prevention of conduct disorders, the prevention of school dropout or improvement in academic performance.

Considering the extent of the results, we focused on the specific topic of bullying and cyberbullying. We expanded the systematic research using more specific keywords ("bullying", "cyberbullying", "school based") always in the time interval from 2000 to 2013 in an online medical database (PubMed/Medline) and, specifically, in an online psychological and social database (Ebsco). Additionally, we contacted the experts in the field of action and preventive bullying research and asked them whether they knew about relevant studies not published in peer-reviewed journals or other relevant literature.

This search yielded 2058 articles; 2020 were excluded because they were present in both databases or were described as quasi-experimental study designs. We also considered it relevant to confine the study design to experimental research and we selected Randomized Control Trial (RCT).

The decision to include only RCT studies limits the effect selection and helps to determine the effectiveness and the repetitiveness of the actions.

Subject recruitment for school-based interventions can be done on several levels in randomized controlled trials, but we did not make further selections based on this criterion. Additionally, we used another criterion to analyze the selected documents: the focus of the study had to be on the operative and preventive school interventions against bullying and cyberbullying. The language used to describe the work and papers' translations and transcriptions into English were also taken into account. Each article was analyzed to determine the study method, the intervention components, the measured outcomes, and the results. 


\section{RESULTS}

We conducted a systematic review of 17 studies that met the inclusion criteria. The selection steps are illustrated in the flow diagram in Fig. (1). Overall, the studies are distributed globally with a prevalence in extra-European countries: 8 studies on the efficacy of anti-bullying intervention programs took place in the USA and 3 were conducted in Australia. The remaining 6 took place in Europe and, as shown in Table 1, in Northern countries mostly.

We divided the studies in two main areas: universal interventions and focused ones. The first area comprises programs with a systemic or ecological approach, oriented to the involvement of the entire school population and frequently necessitating specific actions to involve families. Their theoretical assumptions are that the cultural climate may promote or diminish events of violence among peers, according to the greater or lesser tolerance that they encounter.

Other studies focused on interventions on the specific categories of bullies, victims or bystanders (the protagonists of bullying).

There were also studies comparing the two types of intervention (universal and focused), or proposing a combination of the two, to evaluate the differences in terms of areas and dimensions of the phenomenon and to see if the two types of program can increase each other's efficacy.
Many interventions against bullying are aimed at contrasting the phenomenon and at the same time, at preventing the development of future behavioral or psychiatric symptoms, such as social anxiety, low sense of self-efficacy, social withdrawal, suicidal tendencies and other effects reported to be associated to peer victimization and to living in a social context characterized by high exposition to violence and lack of personal security.

For this reason we considered as a primary aspect of our analysis of intervention programs, their efficacy in reducing bullying - defined as violent behaviors against peers - victimization or bystanders' attitudes and behaviors. As a second step we considered the effect of the actions on other dimensions of psycho-social well-being, as shown in Table 5. We purposefully chose to keep this distinction even when the reduction of bullying-related behaviors was not the primary outcome of the study, and the assessment of action efficacy was related to that specific aspect, while the other aspects of personal well-being could be considered as an added value of each specific intervention, having relation to the general purpose of mental health promotion that drives the actions against bullying.

Most of the interventions we assessed were addressed to the primary school $(\mathrm{N}=12)$; only one was aimed at a teenage population, while 4 studies evaluated the effectiveness of the program more on adolescents than on primary-school children. In particular the Kiva program is developed for children of different ages.

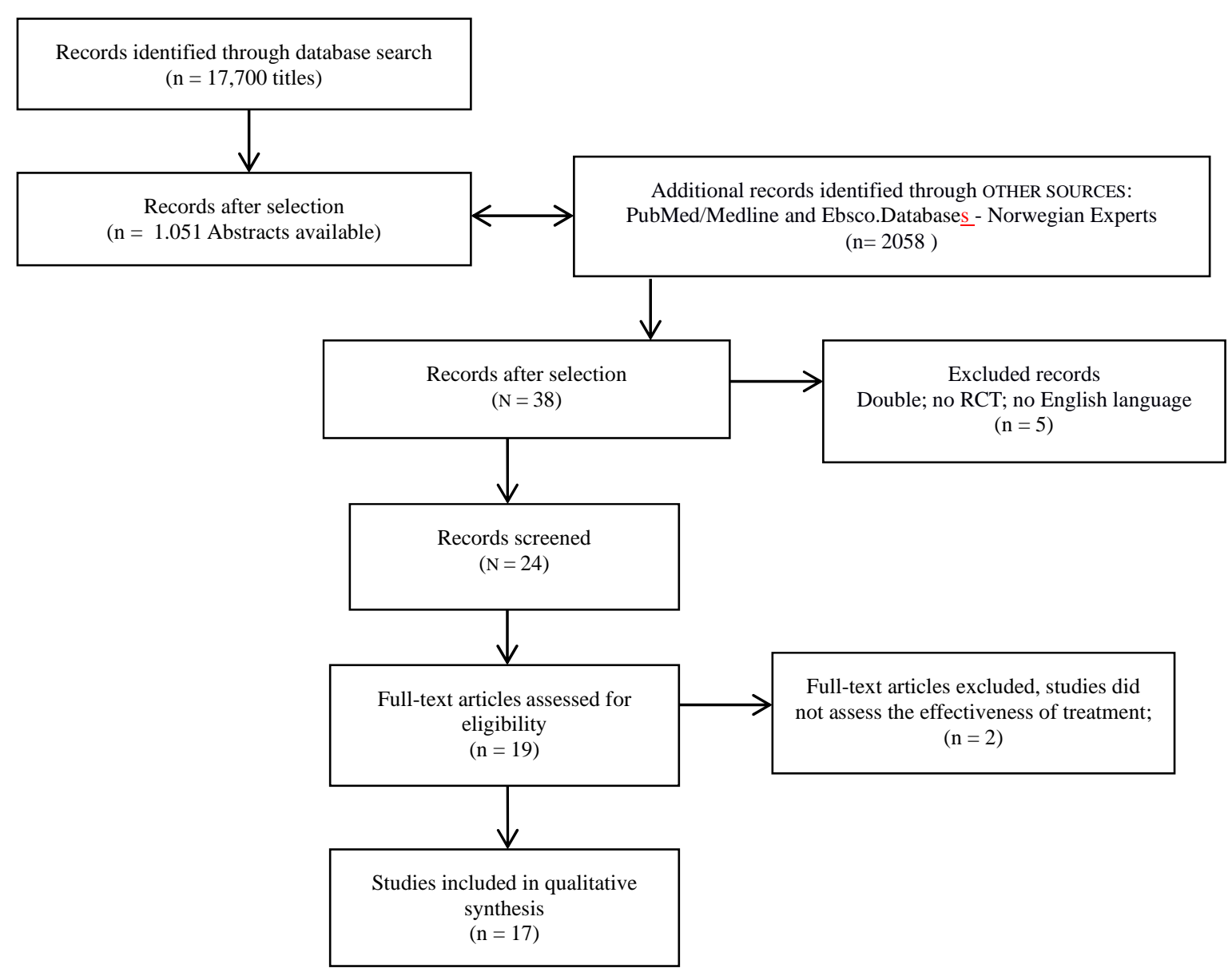

Fig. (1). Flow diagram. 
Table 1. Anti-bullying intervention programs by country.

\begin{tabular}{|c|c|c|c|}
\hline European Countries & N & Non-European Countries & N \\
\hline \hline Finland & 3 & USA & 8 \\
\hline Switzerland & 1 & Australia & \\
\hline Belgium & 1 & & TOT 11 \\
\hline The Netherlands & 1 & & \\
\hline
\end{tabular}

Generally, it seems that the results of the selected studies show higher efficacy of whole-school interventions at the end of the trial, but several outcomes often appeared lower in or deprived of any significance at the follow-up (as shown in Table 4, at the end of the following paragraphs that describe the anti-bullying programs). Few programs showed longterm efficacy, while others demonstrated improvements in the social school climate and well-being of the children, reduction of the impact of the effects of bullying on the subject's well-being. For a detailed description of each approach and level of program, please refer to Table 3.

The following paragraphs give a description of the antibullying intervention programs for each of the methodological studies summarized in Table 2.

\section{Focused Interventions}

Two studies were targeted at intervention programs for students, on an individual level. These studies were conducted by De Rosier [23] and by Berry [24], were based respectively on the implementation of social skills and on a cognitive-behavioral manualized group intervention.

The research conducted by De Rosier showed that the S.S.GRIN intervention (see Table 2 for description) effectively reduces aggressive behavior and forms of antisocial affiliation between peers. However, effect sizes were modest [23]. While the research conducted by De Rosier was targeted at 3rd grade children, the second intervention carried out by Berry focused on male adolescents only, selected among students who reported a clinical level of anxiety and reported having been victims of bullying acts. Adolescents received 8 weekly hour-long sessions of a cognitive behavioral manualized group intervention program, provided in the schools during school time. The program also included actions targeted at the parents' group and delivered at school as well, either during school time or in the evening, depending on the recommendations of each school [24]. Adolescents and parents in the intervention group reported significantly greater reductions in bullying interference. However, most measures showed no significant change at the follow up, indicating maintenance of benefits.

Both interventions proved effective in reducing bullying. Only Berry's study had a follow up measure, with moderate evidence of results maintenance, while both involved a relatively small sample, $\mathrm{N}=187$ and $\mathrm{N}=46$ respectively.

\section{Universal Interventions}

All the programs with a universal approach adopt a social theoretical foundation and act on more levels, with the in- volvement of teachers and, at times, of parents in the implementation of the program. The general theory behind this kind of intervention is that bullying may be related to the general social climate in the school. Therefore, these programs are directed at changing the school climate. All the programs with a school-wide approach included the use of a manual for the implementation of the activities; some studies involved specific actions oriented also to the families, in the form of meetings, training, and classroom lessons [25-31] or home activities [32].

Some programs are defined "whole school" and include several intervention levels (classroom, teacher, parents, students: individually and in group). Others can be defined "multi-level" since they consider fewer levels than the former. Finally, we selected a systemic-approach program that applies many actions to the classroom level only.

\section{The Whole-School Interventions}

We found 7 RCTs involving school-wide level of action (whole-school interventions [33] Sugai, Horner, 2002). Three of these $[25,34,35]$ made reference to the principles of the program developed by Dan Olweus [36] and by Peter K. Smith [6], the pioneers of bullying and cyber-bullying studies. Olweus [14] proposed the idea of anti-bullying intervention programs to improve the social environment by introducing clear rules against the bullying behavior, to reduce the benefits of bullying and increase awareness of its disadvantages. He developed a program that actively involves parents, peers and teachers and believed in the importance of the authoritative presence of the adults taken from the child-rearing model, and applied to the school setting [37].

The Flemish school-based bullying intervention program conducted by Stevens [34] was carried out in primary and secondary schools with different results. The work group proved that the antibullying intervention had a mixed pattern of positive changes in primary schools, while it was not effective in the dimensions of self-referred victimization. In the secondary school the program showed better outcomes on both bullying and victimization [38]. The core program by Fekkes [25] was developed over a period of two years, and recorded improvement in self-reported peer relationships and decreased depression. In Fonagy's workgroup, Twemlow [35] developed the Peaceful intervention program and published the results of "Peaceful Schools Experiment" showing a decrease in peer-reported victimization, aggression, and aggressive and disruptive classroom behavior [35]. The study conducted with the application of the School wide 
Table 2. Characteristic studies: description of each program; sample; age; outcome; tools; type of approach to the intervention program.

\begin{tabular}{|c|c|c|c|c|c|}
\hline Authors & Program & $\begin{array}{l}\text { Type of } \\
\text { intervention }\end{array}$ & $\begin{array}{l}\text { Sample } \\
\text { (IG: Intervention Group; } \\
\text { CG: control group) }\end{array}$ & Age group & Tools (and outcomes) \\
\hline $\begin{array}{l}\text { Fekkes } \text { et al., } \\
\text { the Netherlands } \\
2006\end{array}$ & $\begin{array}{l}\text { The Core program of Olweus D. revisited } \\
\text { An important part of the program is the training } \\
\text { provided to teachers. Another important component } \\
\text { is the development of a written antibullying school } \\
\text { policy describing the activities that the school plans } \\
\text { to perform during the school years. At the beginning } \\
\text { of the school year school board supervisors meet the } \\
\text { parties involved to explain the program and create } \\
\text { support. }\end{array}$ & $\begin{array}{l}\text { Universal } \\
\text { (whole } \\
\text { school) }\end{array}$ & $\begin{array}{l}\text { First Year } \\
\text { IG: } 34 ; \\
\text { CG1: } 37 \text {; } \\
\text { CG2: } 36 \\
\text { Second Year } \\
\text { IG: } 29 \text {; } \\
\text { CG1: } 41 \text {; } \\
\text { CG2: } 35\end{array}$ & $\begin{array}{l}\text { primary } \\
\text { school }\end{array}$ & $\begin{array}{l}\text { - Dutch version of the Olweus Bully/Victim } \\
\text { Questionnaire (bullying behavior); } \\
\text { - Short Depression Inventory for Children; } \\
\text { - psychosomatic complaints (students were } \\
\text { asked about a series of health symptoms); } \\
\text { - measured with a 7-item scale (delinquent } \\
\text { behavior); } \\
\text { - Dutch School Experience Questionnaire } \\
\text { (satisfaction with school life and peer } \\
\text { relationships). }\end{array}$ \\
\hline $\begin{array}{l}\text { Berry et al., } \\
\text { Australia } \\
2009\end{array}$ & $\begin{array}{l}\text { CBT } \\
\text { Adolescents received } 8 \text { hour-long weekly sessions } \\
\text { of a cognitive behavioral manualized group inter- } \\
\text { vention program, and parents attended a separate } \\
\text { parallel program in 2004. The intervention program } \\
\text { included cognitive-behavioral based anxiety man- } \\
\text { agement strategies. Anxiety management included } \\
\text { one session of psychoeducation, two sessions of } \\
\text { cognitive restructuring and one session on the use of } \\
\text { adaptive coping strategies in bullying situations, } \\
\text { plus a session devoted to the enhancement of social } \\
\text { skills. Self-esteem was dealt with in another session } \\
\text { using cognitive strategies. The final session pro- } \\
\text { vided an overview of all the skills learnt and relapse } \\
\text { prevention. Weekly homework was given and } \\
\text { included practice of strategies in real-life situations. } \\
\text { The parents' program comprised discussion of these } \\
\text { strategies aimed at supporting further generalization } \\
\text { of skills, and also addressed potential parental } \\
\text { maintaining factors, such as parental anxiety. }\end{array}$ & Focused & $\begin{array}{l}\text { Adolescent boys } \\
\text { IG: } 22 \\
\text { GC: } 24 \\
\text { No drop-out }\end{array}$ & $\begin{array}{l}\text { Secondary } \\
\text { school }\end{array}$ & $\begin{array}{l}\text { - Self-report measures and a structured } \\
\text { interview to assess bullying experiences } \\
\text { (BIS); } \\
\text { - Center for Epidemiologic Studies Depres- } \\
\text { sion Scale for Children (CES-DC); } \\
\text { - SCARED Scale is a } 41 \text {-item parent and } \\
\text { child questionnaire that screens for anxiety } \\
\text { disorders among children and adolescents; } \\
\text { - Self-Perception Profile for Children and } \\
\text { Adolescents (SPPC and SPPA) competency } \\
\text { and adequacy in several domains; } \\
\text { - Parents completed the parent version of } \\
\text { the SCARED and the BIS }\end{array}$ \\
\hline $\begin{array}{l}\text { Brown et al., } \\
\text { USA } \\
2011\end{array}$ & $\begin{array}{l}\text { "Steps to respect" } 1^{*} \\
\text { The program aims to include teachers, bullied } \\
\text { children, bullies, uninvolved children and parents in } \\
\text { the effort to lower the bullying behavior. An impor- } \\
\text { tant part of the program is the training provided to } \\
\text { teachers. Another important component is the } \\
\text { development of a written anti-bullying school policy } \\
\text { describing the activities that the school plans to } \\
\text { perform during the course of study. }\end{array}$ & $\begin{array}{l}\text { Universal } \\
\text { (ecological } \\
\text { approach) }\end{array}$ & 2940 & $\begin{array}{l}\text { primary } \\
\text { school }\end{array}$ & $\begin{array}{l}\text { - School Environment Survey (SES) } \\
\text { - Teacher Assessment of Student Behavior } \\
\text { (TASB) } \\
\text { - Student survey. Similar to the SES. }\end{array}$ \\
\hline $\begin{array}{l}\text { Frey et al., } \\
\text { USA } \\
2005\end{array}$ & "Steps to respect" 2* & $\begin{array}{l}\text { Universal } \\
\text { (ecological } \\
\text { approach) }\end{array}$ & $\begin{array}{l}6 \text { schools, grades 3-6; } \\
620 \text { students divided by } \\
\text { grades 3-6, respectively: } \\
278,312,277,259 .\end{array}$ & $\begin{array}{l}\text { primary } \\
\text { school }\end{array}$ & $\begin{array}{l}\text { Teacher rating of peer interaction skills: } \\
\text { Peer-Preferred Social Behavior sub scale of } \\
\text { the Scale of Social Competence and School } \\
\text { Adjustment, Students survey of beliefs and } \\
\text { behavior: What school is like for Me. } \\
\text { Observational coding: collecting multiple } \\
\text { focal-individual samples. }\end{array}$ \\
\hline
\end{tabular}


(Table 2) contd....

\begin{tabular}{|c|c|c|c|c|c|}
\hline Authors & Program & $\begin{array}{l}\text { Type of } \\
\text { intervention }\end{array}$ & $\begin{array}{l}\text { Sample } \\
\text { (IG: Intervention Group; } \\
\text { CG: control group) }\end{array}$ & Age group & Tools (and outcomes) \\
\hline $\begin{array}{l}\text { Williford et al., } \\
\text { Finland } \\
2012\end{array}$ & KiVa $2 *$ & $\begin{array}{l}\text { Universal } \\
\text { (ecological } \\
\text { approach) }\end{array}$ & $\begin{array}{l}\text { IG: } 9,914 \\
\text { CG: } 8,498\end{array}$ & $\begin{array}{l}\text { primary and } \\
\text { secondary } \\
\text { school }\end{array}$ & $\begin{array}{l}\text { cyberbullying and cybervictimization were } \\
\text { assessed via a modified version of the obvq } \\
\text { Olweus }\end{array}$ \\
\hline $\begin{array}{l}\text { Williford et al. } \\
\text { Finland } 2014\end{array}$ & KiVa 3* & $\begin{array}{l}\text { Universal } \\
\text { (ecological } \\
\text { approach) }\end{array}$ & $\begin{array}{l}\text { IG: } 4056 \\
\text { CG: } 3685\end{array}$ & $\begin{array}{l}\text { primary and } \\
\text { secondary } \\
\text { school }\end{array}$ & $\begin{array}{l}\text { - Peer-Reported Victimization Victimization } \\
\text { was measured via a peer-nomination proc- } \\
\text { ess through which each student was nomi- } \\
\text { nated by their peers as either a victim or } \\
\text { non-Victim. } \\
\text { - Perception of Peers: students were also } \\
\text { asked to rate their beliefs about their peers } \\
\text { in general. Student beliefs were measured } \\
\text { using the Generalized Perception-of-Peers } \\
\text { Questionnaire, a 13-item scale that assesses } \\
\text { the extent to which one's peers are consid- } \\
\text { ered supportive, kind, and trustworthy as } \\
\text { opposed to unsupportive, hostile, and } \\
\text { untrustworthy. } \\
\text { - Depression: Students' level of depression } \\
\text { was measured by a 7-item scale derived } \\
\text { from the Beck Depression Inventory BDI. } \\
\text { - Anxiety: Two social anxiety scales, the } \\
\text { Fear of Negative Evaluation and the Social } \\
\text { Avoidance and Distress, were combined to } \\
\text { measure students' level of anxiety. }\end{array}$ \\
\hline $\begin{array}{l}\text { Cross et al., } \\
\text { Australia } 2011\end{array}$ & $\begin{array}{l}\text { "Friendly schools" } \\
\text { was designed using a whole-of-school approach to } \\
\text { help build students' social competence and relation- } \\
\text { ship, reduce the likelihood of bullying, and reduce } \\
\text { the harm students may experience from bullying. It } \\
\text { was based on the Principles of Successful Practice } \\
\text { for Bullying Reduction in Schools developed by the } \\
\text { same research team in } 1999 \text {. } \\
\text { The FS program used three levels of intervention to } \\
\text { involve: the whole school community to build their } \\
\text { commitment and capacity to address bullying; } \\
\text { students' families through awareness-raising and } \\
\text { skill-based self-efficacy activities (family interven- } \\
\text { tion); grade } 4-5 \text { students and their teachers through } \\
\text { the provision of teacher training and comprehensive } \\
\text { teaching and learning support materials (classroom } \\
\text { intervention). }\end{array}$ & $\begin{array}{l}\text { Universal } \\
\text { (whole } \\
\text { school) }\end{array}$ & $\begin{array}{l}29 \text { schools. } \\
\text { IG:1046; } \\
\text { CG: } 922\end{array}$ & $\begin{array}{l}\text { primary } \\
\text { school }\end{array}$ & $\begin{array}{l}\text { Friendly Schools theoretical framework } \\
\text { Bullying (Was bullied; Bullied others; Told } \\
\text { if bullied; Saw another bullied) }\end{array}$ \\
\hline
\end{tabular}


(Table 2) contd....

\begin{tabular}{|c|c|c|c|c|c|}
\hline Authors & Program & $\begin{array}{l}\text { Type of } \\
\text { intervention }\end{array}$ & $\begin{array}{l}\text { Sample } \\
\text { (IG: Intervention Group; } \\
\text { CG: control group) }\end{array}$ & Age group & Tools (and outcomes) \\
\hline $\begin{array}{l}\text { Lewis et al., } \\
\text { USA } \\
2013\end{array}$ & $\begin{array}{l}\text { "Positive Action" } \\
\text { The Positive Action Program includes a Scope and } \\
\text { Sequence K-12 classroom Curriculum with six } \\
\text { components: self-concept, social and emotional } \\
\text { positive actions for managing one's responsibility, } \\
\text { and positive actions directed toward physical and } \\
\text { mental health, honesty, getting along with others, } \\
\text { and continuously improving oneself. Each grade- } \\
\text { level includes } 140 \text { lessons (15-20 minutes each; } \\
\text { Grade K-6) or } 70 \text { lessons ( } 20 \text { minutes each; grade } 7 \\
\text { and higher). The program also includes teacher, } \\
\text { counselor, family, and community training as well } \\
\text { as activities directed towards school-wide climate } \\
\text { development. } \\
\text { During the trial, schools received training and } \\
\text { technical assistance to help ensure a high level of } \\
\text { implementation. }\end{array}$ & $\begin{array}{l}\text { Universal } \\
\text { (whole } \\
\text { school) }\end{array}$ & $\begin{array}{l}14 \text { schools; } \\
1170 \text { students; } \\
\text { IG: } 7 \text { schools; } \\
\text { CG: } 7 \text { schools }\end{array}$ & $\begin{array}{l}\text { primary } \\
\text { school }\end{array}$ & $\begin{array}{l}\text { - The Normative Beliefs About Aggression } \\
\text { Scale (Normative beliefs supporting aggres- } \\
\text { sion); } \\
\text { - Aggression Scale (bullying); } \\
\text { - Child problem-behavior scales (Disruptive } \\
\text { behaviors); } \\
\text { - Sedated from the Risk Behavior Survey } \\
\text { (Violence). } \\
\text { - Versions of the Aggression and Conduct } \\
\text { Problem Subscales of the Behavior and } \\
\text { Assessment System for Children .BASC. } \\
\text { (Parent-Report Measures) }\end{array}$ \\
\hline $\begin{array}{l}\text { Li et al., USA } \\
2011\end{array}$ & $\begin{array}{l}\text { "Positive Action" } \\
\text { In this trial program schools received the K-8 } \\
\text { portion of the PA classroom curriculum and } \\
\text { school/staff training from the program developer, } \\
\text { plus kits for school preparation, school-wide climate } \\
\text { development, counseling and family classes. The K- } \\
\text { PA classroom curriculum with scope and sequence } \\
\text { consists of over } 140 \text { 15-min, age-appropriate lessons } \\
\text { per grade that are designed to be taught } 4 \text { days per } \\
\text { week. }\end{array}$ & $\begin{array}{l}\text { Universal } \\
\text { (whole } \\
\text { school) }\end{array}$ & $\begin{array}{l}\text { CG: } 400(\mathrm{~T} 0) \\
240 \text { analyzed } \\
\text { IG: } 410(\mathrm{~T} 0) \\
260 \text { analyzed }\end{array}$ & $\begin{array}{l}\text { primary } \\
\text { school }\end{array}$ & $\begin{array}{l}\text { Bulling (Aggression Scale, } 12 \text { items); } \\
\text { disruptive behaviors (the frequency of } \\
\text { delinquent behavior scale, modified to refer } \\
\text { to the school context, } 6 \text { items) } \\
\text { Unit Implementation Report for teachers to } \\
\text { measure program implementation } \\
\text { Life time prevalence of substance use and } \\
\text { serious violence-related behavior (scale of } \\
\text { measures not indicated) }\end{array}$ \\
\hline $\begin{array}{l}\text { Twemlow et } \\
\text { al., USA } \\
2005\end{array}$ & $\begin{array}{l}\text { "The Paceful schools experiment" } \\
\text { The components of the program philosophy in- } \\
\text { cluded the following: } \\
\text { Positive climate campaigns } \\
\text { Classroom management (discipline plan) } \\
\text { Peer and adult mentorship } \\
\text { The gentle warrior physical education program } \\
\text { Reflection time }\end{array}$ & $\begin{array}{l}\text { Universal } \\
\text { (whole } \\
\text { school) }\end{array}$ & $\begin{array}{l}9 \text { schools } \\
\text { IG: } 3600\end{array}$ & $\begin{array}{l}\text { primary } \\
\text { school }\end{array}$ & $\begin{array}{l}\text { - Peer and self-reports of bullying and } \\
\text { victimization; } \\
\text { - Peer reports of aggressive and helpful by- } \\
\text { standing; } \\
\text { - Self-reports of empathy toward victims of } \\
\text { bullying; } \\
\text { - Self-reports of belief that aggression is } \\
\text { legitimate; } \\
\text { - Classroom behavioral observation of } \\
\text { disruptive and off task behavior. }\end{array}$ \\
\hline $\begin{array}{l}\text { Waasdorp et } \\
\text { al., USA } 2012\end{array}$ & $\begin{array}{l}\text { "Positive Behavioral Interventions and Supports" } \\
\text { (SWPBIS) } \\
\text { SWPBIS is a noncurricular, universal prevention } \\
\text { model that draws on behavioral and social learning, } \\
\text { and organizational principles. The model aims to } \\
\text { alter the school environment by creating improved } \\
\text { systems (e.g., discipline and data management) and } \\
\text { procedures (e.g., office referral, behavioral rein- } \\
\text { forcement) that promote positive changes in staff } \\
\text { and student behaviors. A SWPBIS team coordinates } \\
\text { the program and establishes } 3 \text { to } 5 \text { positively stated } \\
\text { school-wide expectations regarding student behavior } \\
\text { (e.g., "be respectful, responsible, and ready to } \\
\text { learn") that are posted across settings, taught to all } \\
\text { students and staff, and reinforced through praise and } \\
\text { tangible rewards (e.g., tickets). The SWPBIS is } \\
\text { implemented in all classroom and non-classroom } \\
\text { contexts. }\end{array}$ & $\begin{array}{l}\text { Universal } \\
\text { (whole } \\
\text { school) }\end{array}$ & $\begin{array}{l}\text { IG: } 6614 \\
\text { CG: } 5124\end{array}$ & $\begin{array}{l}\text { primary } \\
\text { school }\end{array}$ & $\begin{array}{l}\text { Reports from teachers on bully-related } \\
\text { behaviors (assessed through the teacher } \\
\text { observation of classroom adaptation - } \\
\text { checklist, TOCA-C). }\end{array}$ \\
\hline
\end{tabular}


(Table 2) contd....

\begin{tabular}{|c|c|c|c|c|c|}
\hline Authors & Program & $\begin{array}{l}\text { Type of } \\
\text { intervention }\end{array}$ & $\begin{array}{l}\text { Sample } \\
\text { (IG: Intervention Group; } \\
\text { CG: control group) }\end{array}$ & Age group & Tools (and outcomes) \\
\hline $\begin{array}{l}\text { De Rosier } e t \\
\text { al., USA } \\
2004\end{array}$ & $\begin{array}{l}\text { "Social Skills Group Intervention" (S.S.GRIN). } \\
\text { It is a structured manualized intervention. } \\
\text { The goal of this project was to develop a generic } \\
\text { social skills training intervention that could be } \\
\text { applied to a wide variety of social problems by } \\
\text { targeting both prosocial and inhibitory skills. Given } \\
\text { the comorbidity of psychopatology and peer prob- } \\
\text { lems as well as internalizing and externalizing } \\
\text { disorders, social skills interventions with a more } \\
\text { general scope of application may be more efficient. } \\
\text { Similarly to universal programs that apply an } \\
\text { intervention to a broad population, the reduction of } \\
\text { multiple problem areas may be produced by the } \\
\text { application of a single intervention aimed at build- } \\
\text { ing relationships. }\end{array}$ & Focused & $\begin{array}{l}\text { IG:187 } \\
\text { CG:194 }\end{array}$ & $\begin{array}{l}\text { primary } \\
\text { school }\end{array}$ & $\begin{array}{l}\text { Social interaction survey: social self- } \\
\text { perception; } \\
20 \text {-item measure by Ollendick and Schmidt } \\
\text { for measuring self-efficacy and expectancy; } \\
\text { The 22-item social anxiety scale for chil- } \\
\text { dren revised: social anxiety with peers; } \\
\text { 6-item social self worth subscale of the self- } \\
\text { perception profile for children: self-esteem; } \\
\text { 13-item mood and feeling questionnaire - } \\
\text { short form: depressive symptoms. }\end{array}$ \\
\hline $\begin{array}{l}\text { Fonagy et al., } \\
\text { Australia } \\
2009\end{array}$ & $\begin{array}{l}\text { "School Psychiatric Consultation and } \\
\text { Creating a Peaceful School Learning Environment" } \\
\text { (CAPSLE) } \\
\text { School Psychiatric Consultation } \\
\text { Three child psychiatry residents, supervised bi- } \\
\text { weekly by a senior child psychiatrist, delivered } \\
\text { mental health consultation following the SPC } \\
\text { manual for four hours a week throughout the first } \\
\text { two school years. } \\
\text { A CAPSLE team drawn from school staff in the } \\
\text { pilot project led implementation in Years } 1 \text { and } 2 \\
\text { using a training manual. }\end{array}$ & $\begin{array}{l}\text { Universal } \\
\text { (whole } \\
\text { school) }\end{array}$ & $\begin{array}{l}\text { IG } 1: 563 \\
\text { IG } 2: 422 \\
\text { CG: } 360\end{array}$ & $\begin{array}{l}\text { primary } \\
\text { school }\end{array}$ & $\begin{array}{l}\text { Peer and self-reports about bullying, by- } \\
\text { standing, and mentalizing behavior and } \\
\text { classroom behavioral observations of } \\
\text { disruptive and off-task behavior. Peer } \\
\text { nominations of aggression, victimization } \\
\text { and by-standing. } \\
\text { Self-reports of aggression, victimization, } \\
\text { and mentalizing. The Peer Experiences } \\
\text { Questionnaire. Observations of classroom } \\
\text { behavior. Each child was observed for } \\
\text { twenty } 30 \text {-second intervals on three differ- } \\
\text { ent days using classroom observation } \\
\text { procedures. }\end{array}$ \\
\hline
\end{tabular}


Table 3. Approach and level of intervention program.

\begin{tabular}{|c|c|c|c|c|c|c|}
\hline Authors & Program & $\begin{array}{l}\text { Whole } \\
\text { school }\end{array}$ & Classroom & $\begin{array}{l}\text { Teachers/ } \\
\text { Staff }\end{array}$ & Family & Students \\
\hline Cross et al. 2011 & "Friendly schools" & $\mathrm{x}$ & $\mathrm{x}$ & $\mathrm{x}$ & $\mathrm{x}$ & $\mathrm{x}$ \\
\hline Brown et al. 2011 & "Steps to Respect" & & $\mathrm{x}$ & $\mathrm{x}$ & $\mathrm{x}$ & \\
\hline Frey et al. 2005 & "Steps to Respect" & & $\mathrm{x}$ & $\mathrm{x}$ & & \\
\hline Fonagy et al. 2009 & $\begin{array}{l}\text { School Psychiatric Consultation } \\
\text { "Creating a Peaceful School Learning Environment" } \\
\text { (CAPSLE) }\end{array}$ & & $\mathrm{x}$ & $\mathrm{x}$ & $\mathrm{x}$ & $\mathrm{x}$ \\
\hline Malti et al. 2011 & $\begin{array}{l}\text { "Promoting Alternative Thinking Strategies" (PATHS) } \\
\text { "Triple-P" } \\
\text { PATHS+Triple-P }\end{array}$ & & $\begin{array}{l}\mathrm{x} \\
\mathrm{x}\end{array}$ & & $\begin{array}{l}\mathrm{x} \\
\mathrm{x}\end{array}$ & \\
\hline DeRosier 2004 & "Social Skills Group Intervention" (S.S.GRIN) & & & & & $\mathrm{x}$ \\
\hline Stevens et al. 2000 & Flemish school based bullying intervention program & $\mathrm{x}$ & $\mathrm{x}$ & $\mathrm{x}$ & $\mathrm{x}$ & $\mathrm{x}$ \\
\hline Li et al. 2011 & "Positive Action" & $\mathrm{x}$ & $\mathrm{x}$ & $\mathrm{x}$ & $\mathrm{x}$ & \\
\hline Lewis et al. 2013 & "Positive Action" & $\mathrm{x}$ & $\mathrm{x}$ & $\mathrm{x}$ & $\mathrm{x}$ & \\
\hline Berry \& Hunt 2009 & CBT & & & & $\mathrm{x}$ & $\mathrm{x}$ \\
\hline $\begin{array}{l}\text { Waasdorp et al. } \\
2012\end{array}$ & $\begin{array}{l}\text { "Positive Behavioral Interventions and Supports" } \\
\text { (SWPBIS) }\end{array}$ & $\mathrm{x}$ & & $\mathrm{x}$ & & $\mathrm{x}$ \\
\hline $\begin{array}{l}\text { Kärnä et al. } 2011 \\
\text { Williford et al. } \\
2012 \\
\text { Williford et al. } \\
2014\end{array}$ & $\mathrm{KiVa}$ & & $\mathrm{x}$ & $\mathrm{x}$ & $\mathrm{x}$ & $\mathrm{x}$ \\
\hline
\end{tabular}

Positive Behavioral Intervention and Supports (SWPBIS) showed that children in the SWPBIS schools displayed significantly less bullying behavior and experienced lower levels of rejection over time than children in the control schools [39].

Cross' [32] Friendly Schools (FS) intervention program monitored bullying behaviors at 12, 24 and 36 months, and observed less reported victimization episodes at 12 and 36 months, but found no difference in the self-report measures related to bullying, with a lack of internal coherence of the measures*. The Positive Actions program in the studies conducted by Lewis [27, 31] showed similar inconsistency*. Lewis [31] reports that there was no evidence of the effect of the program in relation to the reports of teachers regarding bullying and the behavioral problems of the students, while the students themselves, at the end of the program, reported less violent behaviors in comparison to the students in the control group. Li [27], who worked on a similar program, reported that the Positive Actions Program brought $41 \%$ fewer bullying behaviors (IRR $=0.59)$ compared to students in the control schools. Disruptive behaviors showed similar results, but at a non-statistically significant level. It is important to consider that this study did not have any baseline data for about half of the sample.

\section{Multi-Level Systemic Approach}

Several intervention programs contain a lower number of action levels, including also an ecologic approach to bullying, i.e. to see youth behaviors as "shaken by multiple factors within nested contextual systems" [40]. They are treated by Brown [41], Frey [42], Karna [28] and Willford [29, 30], respectively, with the models "Step to Respect" (STR) and "The KiVa Program".

The Step to Respect program is designed to reduce bullying partly by decreasing peer reinforcement of bullying behavior through increased positive bystander behaviors (ignoring bullying, supporting bullied students, intervening to stop bullying incidents and reporting bullying to school staff). The work proposed by Frey showed that the students in the intervention schools were accepting less of bullying/aggression, felt more responsibility to intervene to help bullied friends, and reported greater adult responsiveness than the students in the control schools [42]. This result supported the results of Brown's work, published in 2011: the author showed the positive effects of the program on a range of outcomes (e.g., improved student climate, lower levels of physical bullying perpetration, less bullying-related problems at school). 
Table 4. Program efficacy (efficacy evaluated for bullying, victimization or by-standing).

\begin{tabular}{|c|c|c|c|c|c|c|}
\hline Authors & Program & $\begin{array}{l}\text { Duration of } \\
\text { Intervention }\end{array}$ & Follow-up & Main Effects & Efficacy & Results \\
\hline $\begin{array}{l}\text { Cross et al. } \\
2011\end{array}$ & $\begin{array}{l}\text { "Friendly } \\
\text { schools" }\end{array}$ & Two-year trial & one year & $\begin{array}{l}\text { Bullying, } \\
\text { Victimization }\end{array}$ & moderate* & $\begin{array}{l}\text { IG were significantly less likely to observe bullying at } 12,24 \text { and } 36 \\
\text { months and be bullied after } 12 \text { and } 36 \text { months, and significantly } \\
\text { more likely to tell if bullied after } 12 \text { months than comparison } \\
\text { students. } \\
\text { No differences were found for self-reported perpetration of bullying. } \\
\text { At baseline: the two study conditions were similar with regard to the } \\
\text { frequency of being bullied }(\chi 2(2, \mathrm{n}=1963)=0.35, \mathrm{p}=.841) \text {, of } \\
\text { bullying others }(\chi 2(2, \mathrm{n}=1957)=1.82, \mathrm{p}=.403) \text { and of telling if } \\
\text { bullied }(\chi 2(1, \mathrm{n}=1956)=0.4, \mathrm{p}=.505) \text {; they differed with regard } \\
\text { to whether students had seen another Year- } 4 \text { or younger student } \\
\text { being bullied }(\chi 2(1, \mathrm{n}=1945)=6.2, \mathrm{p}=.013) \text {. Overall } 14 \% \text { ( } \mathrm{n}= \\
274) \text { of students reported bullying another student, on their own or } \\
\text { as part of a group. } \\
\text { Significant differences between the study conditions in the first and } \\
\text { third years of the study. }\end{array}$ \\
\hline $\begin{array}{l}\text { Brown et al. } \\
2011\end{array}$ & $\begin{array}{l}\text { "Steps to } \\
\text { respect" }\end{array}$ & $\begin{array}{l}\text { Fall pretest } \\
\text { Spring post test }\end{array}$ & one year & $\begin{array}{l}\text { Bullying, } \\
\text { Victimization, } \\
\text { Student climate }\end{array}$ & moderate & $\begin{array}{l}\text { Significant positive effects }(\mathrm{p}=.05) \text { of the program on a range of } \\
\text { outcomes. Results of this study support the program as an effective } \\
\text { intervention for the prevention of bullying in schools. } \\
\text { Effect size ( } 0.13 \text { ) for social competency. } \\
\text { Small effect size reported in this study may be seen as a limitation; } \\
\text { additional effects of model covariates indicated differences in mean } \\
\text { levels of bullying-related behaviors across gender, racial and age } \\
\text { groups. } \\
\text { School Antibullying Policies and Strategies } 0.38 \\
\text { Student Bullying Intervention } 0.28 \\
\text { Staff Bullying Intervention na } \\
\text { Student Climate } 0.21 \\
\text { Staff Climate } 0.26 \\
\text { School Bullying-Related Problems }-0.35\end{array}$ \\
\hline Frey et al. 2005 & $\begin{array}{l}\text { „Steps to } \\
\text { respect“ }\end{array}$ & Three years & one year & $\begin{array}{l}\text { Bullying, } \\
\text { Aggressive by- } \\
\text { standers, social- } \\
\text { emotional skills }\end{array}$ & high & $\begin{array}{l}\text { Acceptance of bullying/aggression } \mathrm{F}(1,73.8)=8.51 \mathrm{p}<.01 \\
\text { Bystander responsibility } \mathrm{F}(1,93.3)=3.93 \mathrm{p}<.05 \\
\text { Perceived adult responsiveness } \mathrm{F}(1,93.2)=5.30 \mathrm{p}<.05 \\
\text { Difficulty in responding assertively } \mathrm{F}(1,63.0)=3.14 \mathrm{p}<.10 \\
\text { Direct aggression } \mathrm{F}(1,68.7)=2.05 \\
\text { Indirect aggression } \mathrm{F}=1 \\
\text { Victimization } \mathrm{F}(1,72.4)=3.74 \mathrm{p}<.10\end{array}$ \\
\hline $\begin{array}{l}\text { Jenson \& } \\
\text { Dietrich } 2007\end{array}$ & "Youth matters" & Two-year trial & one year & $\begin{array}{l}\text { Bullying, } \\
\text { Victimization }\end{array}$ & not effective & $\begin{array}{l}\text { Outcomes from the YM investigation reveal limited evidence of a } \\
\text { positive impact on one dimension of bullying behavior. Small } \\
\text { improvements were observed among students in the experimental } \\
\text { condition on a measure of bully victimization in a continuous } \\
\text { outcome growth model. } \\
\text { Results indicate that self-reported bully victimization among } \\
\text { students in the YM schools decreased at a higher rate compared to } \\
\text { students in control group schools, and by the end of the study, bully } \\
\text { victimization was significantly lower in the YM condition relative to } \\
\text { the control condition. } \\
\text { Bym }-0.171, t \text { value }=-2.074 \text {. the critical t- value for the two tailed } \\
\text { test with } 25 \text { degrees of freedom is } 2.06 \text {. }\end{array}$ \\
\hline
\end{tabular}


(Table 4) contd....

\begin{tabular}{|c|c|c|c|c|c|c|}
\hline Authors & Program & $\begin{array}{l}\text { Duration of } \\
\text { Intervention }\end{array}$ & Follow-up & Main Effects & Efficacy & Results \\
\hline $\begin{array}{l}\text { Fonagy et al. } \\
2009\end{array}$ & $\begin{array}{l}\text { School Psychi- } \\
\text { atric Consulta- } \\
\text { tion and } \\
\text { "Creating a } \\
\text { Peaceful School } \\
\text { Learning } \\
\text { Environment" } \\
\text { (CAPSLE) }\end{array}$ & Two-year trial & one year & $\begin{array}{l}\text { Aggression, } \\
\text { victimization, } \\
\text { by-standers, } \\
\text { empathy for } \\
\text { victims, mental- } \\
\text { izing behaviors }\end{array}$ & $\begin{array}{l}\text { SPC } \\
\text { Moderate } \\
\text { efficacy } \\
\text { CAPSALE } \\
\text { High efficacy }\end{array}$ & 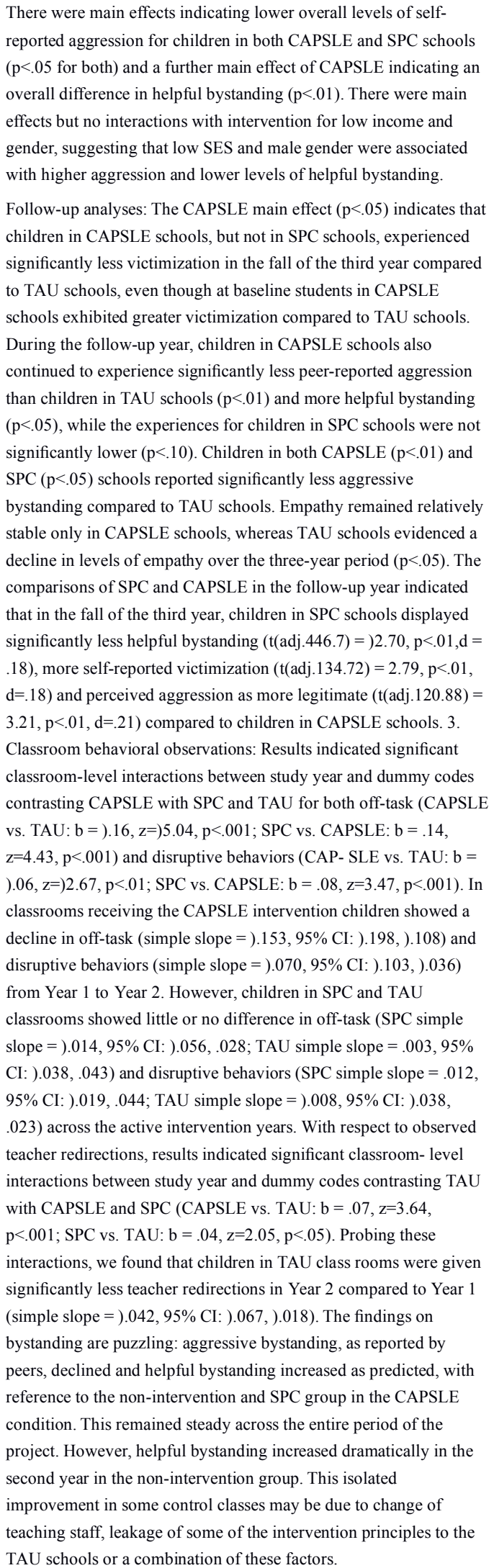 \\
\hline
\end{tabular}


(Table 4) contd....

\begin{tabular}{|c|c|c|c|c|c|c|}
\hline Authors & Program & $\begin{array}{l}\text { Duration of } \\
\text { Intervention }\end{array}$ & Follow-up & Main Effects & Efficacy & Results \\
\hline $\begin{array}{l}\text { Fekkes et al. } \\
2006\end{array}$ & $\begin{array}{l}\text { The Core } \\
\text { program of } \\
\text { Olweus D. } \\
\text { revisited }\end{array}$ & One year trial & one year & $\begin{array}{l}\text { Bullying, } \\
\text { depression, } \\
\text { psychosomatic } \\
\text { complaints, } \\
\text { delinquent } \\
\text { behavior, school } \\
\text { life satisfaction }\end{array}$ & $\begin{array}{l}\text { Low efficacy at } \\
\text { the follow-up }\end{array}$ & $\begin{array}{l}\text { The intervention group showed a decline in the scale scores of: } \\
\text { victimization }(-1.06 \text { vs } 0.28 ; \text { P } .01) \text {; active bullying behaviors } \\
(-0.47 \text { vs } 0.12, P .05) \text {. } \\
\text { Intervention schools: Self-reported peer relationships improved } \\
(0.48 \text { vs } 0.11 ; \text { P } .05) \text {; decrease in reported depression ( }-0.33 \text { vs } \\
-0.10 ; \text { P } .10) \text {. } \\
\text { At follow-up, there were no differences between the intervention } \\
\text { and control groups for the outcome measures. }\end{array}$ \\
\hline Malti et al. 2011 & $\begin{array}{l}\text { "Promoting } \\
\text { Alternative } \\
\text { Thinking } \\
\text { Strategies" } \\
\text { (PATHS) } \\
\text { "Triple-P" } \\
\text { PATHS+Triple- } \\
\text { P }\end{array}$ & Two years trial & two tears & $\begin{array}{l}\text { Externalizing } \\
\text { behaviors, } \\
\text { social compe- } \\
\text { tence, nonag- } \\
\text { gressive exter- } \\
\text { nalizing behav- } \\
\text { iors }\end{array}$ & \begin{tabular}{|l} 
PATHS \\
High efficacy, \\
TRIPLE - P \\
Moderate \\
efficacy
\end{tabular} & $\begin{array}{l}\text { According to teacher reports, the PATHS intervention was more } \\
\text { effective than no intervention in reducing children's long-term } \\
\text { impulsivity/adhd and aggressive behavior. In the } 5 \text { th year, or } \\
\text { maintenance phase, PATHS remained superior to no intervention in } \\
\text { terms of teacher-reported externalizing behavior. } \\
\text { According to the parent reports, PATHS contributes to reducing } \\
\text { aggressive behavior. Moderate effect size for the primary long-term } \\
\text { outcome variables. } \\
\text { By contrast, the triple-p intervention had no significant effect on } \\
\text { children's overt externalizing behavior, and the paths + triple-p } \\
\text { treatment did not have any stronger effect on externalizing behavior } \\
\text { than paths alone. However, parents, teachers and children can } \\
\text { provide inconsistent data regarding problem behavior in children. } \\
\text { Teacher rating of externalizing symptoms suggests that children in } \\
\text { paths condition showed a greater overall decline in the externalizing } \\
\text { symptoms of aggressive behavior and impulsivity than their c.g. } \\
\text { counterparts on SBQ (both }<.05 \text { ). Moderate effect size: } \mathrm{d}=0.42 \text { for } \\
\text { Aggr. Behavior and d= } 0.46 \text { for impulsivity scores. } \\
\text { Child -reported aggressive behavior was predicted by the child } \\
\text { being male and by having a Swiss background. } \\
\text { Second major finding: the intervention did not increase any of the } \\
\text { tested dimensions of social competence (i.e. prosocial behavior and } \\
\text { socio cognitive skills). }\end{array}$ \\
\hline Li et al. 2011 & $\begin{array}{l}\text { "Positive } \\
\text { Action" }\end{array}$ & Three-year trial & & $\begin{array}{l}\text { Substance use, } \\
\text { violence- related } \\
\text { behavior, } \\
\text { bullying, self- } \\
\text { efficacy, beliefs } \\
\text { about aggres- } \\
\text { sion }\end{array}$ & High efficacy* & $\begin{array}{l}\text { The positive action program proved effective against: substance use, } \\
\text { bullying, violent behavior. } \\
\text { Not statistically significant for non-disruptive behavior. } \\
\text { Findings indicated that students in the intervention group endorsed } \\
31 \% \text { fewer substance use behaviors (incidence rate ratio [IRR] = } \\
0.69), 37 \% \text { fewer violence-related behaviors (IRR }=0.63 \text { ) and } 41 \% \\
\text { fewer bullying behaviors (IRR }=0.59) \text {, respectively, compared to } \\
\text { students in the control schools. Reduction in reported disruptive } \\
\text { behaviors was of a similar magnitude ( } 27 \%, \text { IRR }=0.73 \text { ), but was } \\
\text { not statistically significant. } \\
\text { Limitations: the study did not have baseline data for about half of } \\
\text { the sample: a self-report of negative behaviors was used as a basis } \\
\text { for outcomes measures; a relatively small number of schools; the } \\
\text { mobility of students in this study was relatively high. }\end{array}$ \\
\hline
\end{tabular}


(Table 4) contd....

\begin{tabular}{|c|c|c|c|c|c|c|}
\hline Authors & Program & $\begin{array}{l}\text { Duration of } \\
\text { Intervention }\end{array}$ & Follow-up & Main Effects & Efficacy & Results \\
\hline $\begin{array}{l}\text { Lewis et al. } \\
2013\end{array}$ & $\begin{array}{l}\text { "Positive } \\
\text { Action" }\end{array}$ & $\begin{array}{l}\text { Six years and } \\
\text { eight waves }\end{array}$ & & $\begin{array}{l}\text { Beliefs of } \\
\text { aggression, } \\
\text { bullying, } \\
\text { disruptive } \\
\text { behavior, } \\
\text { violence, }\end{array}$ & $\begin{array}{l}\text { not effective } \\
\text { against bullying, } \\
\text { moderately } \\
\text { effective for the } \\
\text { beliefs of } \\
\text { aggression }\end{array}$ & $\begin{array}{l}\text { Positive Action mitigated increases over time in youth reports of } \\
\text { normative beliefs supporting aggressive behaviors, and of } \\
\text { engagement in disruptive behavior and bullying (girls only) and (2) } \\
\text { parent reports of youth bullying behaviors (boys only). At study end } \\
\text { point, students in Positive Action schools also reported low ratio of } \\
\text { violence-related behavior than students in control schools. School- } \\
\text { wide findings indicated positive program effects on both disciplinary } \\
\text { referrals and suspensions. } \\
\text { Data also were collected from teachers on bullying and conduct } \\
\text { problems. No evidence of program effects were found on these } \\
\text { outcomes. } \\
\text { Program effect sizes ranged from } 0.26 \text { to } 0.68 \text {. } \\
\text { Several limitations: self-report has potential reporting bias; high } \\
\text { mobility of students and turn over in the study period. }\end{array}$ \\
\hline DeRosier 2004 & $\begin{array}{l}\text { "Social Skills } \\
\text { Group Interven- } \\
\text { tion" } \\
\text { (S.S.GRIN) }\end{array}$ & $\begin{array}{l}\text { Brief } \\
\text { (8 week) }\end{array}$ & & $\begin{array}{l}\text { High dislike, } \\
\text { social anxiety, } \\
\text { victimization }\end{array}$ & $\begin{array}{l}\text { Moderate } \\
\text { efficacy* }\end{array}$ & $\begin{array}{l}\text { Initially aggressive children who participated in the treatment } \\
\text { exhibited significantly lower aggressive behavior, at time } 2 \text {, } \\
\text { according to peers and antisocial affiliations. } \\
\text { There was a significant mutivariate main effect for treatment } \\
\text { condition, } \mathrm{F}(15,221)=1,79, \mathrm{p}<.05 \text {. Univariate analyses reveled that } \\
\text { this effect held for the following areas of adjustment: } \mathrm{p}-\mathrm{r} \text { linking, } \mathrm{F} \\
(1,369)=5,13, \mathrm{p}<.05 ;(\mathrm{b}) \mathrm{s}-\mathrm{r} \text { self esteem, } \mathrm{F}(1,325)=6,46 \mathrm{p}<.05 \text {, (c) s-r } \\
\text { self-efficacy, } \mathrm{F}(1,294)=4,03, \mathrm{p}<.05 ;(\mathrm{d}) \mathrm{s}-\mathrm{r} \text { social anxiety in general, } \\
\mathrm{F}(1,294)=4,16 \mathrm{p}<.05 \text {; and (e) s-r antisocial affiliations, } \\
\mathrm{F}(1,347)=4,28 \mathrm{p}<.05 \text {. } \\
\text { The patterns of change as a function of participation in the } \\
\text { intervention did not differ depending on the reasons for inclusion in } \\
\text { the intervention. No differential effects by gender were found. Boys } \\
\text { and girls benefited equally from participation in treatment. }\end{array}$ \\
\hline $\begin{array}{l}\text { Berry \& Hunt } \\
2009\end{array}$ & CBT & $\begin{array}{l}\text { Brief ( } 8 \text { weekly } \\
\text { hour long- } \\
\text { sessions of } \\
\text { CBT) }\end{array}$ & 3 months & $\begin{array}{l}\text { Anxiety, low } \\
\text { self-esteem, } \\
\text { coping strate- } \\
\text { gies }\end{array}$ & $\begin{array}{l}\text { Moderate } \\
\text { efficacy for } \\
\text { bullying* }\end{array}$ & $\begin{array}{l}\text { Adolescents in the intervention condition from two-parent } \\
\text { households reported increased global self-esteem across time, } \\
\text { whereas those from single parent households }(\mathrm{n}=3) \text { reported a } \\
\text { reduction across time. Children and parents in the intervention } \\
\text { condition reported significantly greater reductions in total bullying } \\
\text { experiences between baseline and post test than controls, } \mathrm{F}(1,44) \\
=25.12, \mathrm{p}<.001 ; \mathrm{F}(1,44)=26.52, \mathrm{p}<.001, \text { respectively. } \\
\text { Adolescents and parents in the intervention condition also reported } \\
\text { significantly greater reductions in bullying interference, } \mathrm{F}(1,44) 1 / 4 \\
29.40, \mathrm{p}<.001 ; \mathrm{F}(1,44) 1 / 449.51, \mathrm{p}<.001 \text { respectively. According } \\
\text { to adolescent and parental reports there were significantly greater } \\
\text { reductions in anxiety symptoms between baseline and post } \\
\text { intervention for those in the intervention condition compared with } \\
\text { controls, } \mathrm{F}(1,44)=27.52, \mathrm{p}<.001 ; \mathrm{F}(1,44)=32.88, \mathrm{p}<.001 \text {, } \\
\text { respectively. } \\
\text { Most measures showed no significant change at the follow up, } \\
\text { indicating maintenance of gains. } \\
\text { Further significant reductions in scores were shown for child- } \\
\text { reported total bullying, } \mathrm{t}(1,21)=3.01, \mathrm{p}<.01 \text {, and child-reported } \\
\text { anxiety, } \mathrm{t}(1,21)=2.46, \mathrm{p}<.05 \text {. }\end{array}$ \\
\hline $\begin{array}{l}\text { Waasdorp et al. } \\
2012\end{array}$ & $\begin{array}{l}\text { "Positive } \\
\text { Behavioral } \\
\text { Interventions } \\
\text { and Supports" } \\
\text { (SWPBIS) }\end{array}$ & Four-year trial & & $\begin{array}{l}\text { Bullying, } \\
\text { rejection by } \\
\text { peers }\end{array}$ & High efficacy & $\begin{array}{l}\text { Analyses indicated that children in schools implementing the } \\
\text { SWPBIS displayed lower rates of teacher-reported bullying and of } \\
\text { peer rejection than those in schools without SWPBIS. A significant } \\
\text { interaction also emerged between grade level of first exposure to } \\
\text { SWPBIS and intervention status, suggesting that the effects of } \\
\text { SWPBIS on rejection were strongest among children who were first } \\
\text { exposed to SWPBIS at a younger age. } \\
\text { The hierarchical linear modeling results indicated that children in } \\
\text { the SWPBIS schools displayed significant less bullying behavior } \\
\text { ( } \mathrm{y}=-0,02, \mathrm{t}=-2,60, \mathrm{p}<.05, \mathrm{SE}=0,01) \text { and experienced lower levels } \\
\text { of rejection }(\mathrm{y}=-0.03, \mathrm{t}=-2,32, \mathrm{p}<0,05, \mathrm{SE}=0,016 \text { ) over time vs } \\
\text { children in the comparison schools. } \\
\text { The significant cross-level interaction effect indicated that children } \\
\text { in higher grades in comparison schools showed greater increases in } \\
\text { rejection relative to their age-mate in SWPBIS schools. } \\
\text { Effective prevention efforts targeting this age group have the } \\
\text { potential to attenuate the typical spike in bullying during middle } \\
\text { school. }\end{array}$ \\
\hline
\end{tabular}


(Table 4) contd....

\begin{tabular}{|c|c|c|c|c|c|c|}
\hline Authors & Program & $\begin{array}{l}\text { Duration of } \\
\text { Intervention }\end{array}$ & Follow-up & Main Effects & Efficacy & Results \\
\hline $\begin{array}{l}\text { Kärnä et al. } 1^{\circ} \\
2011 \\
\text { Williford et al. } \\
2^{\circ} 2012 \\
\text { Williford et al. } \\
3^{\circ} 2014\end{array}$ & KiVa & $\begin{array}{l}\text { Brief (20-hour } \\
\text { lessons) }\end{array}$ & $\begin{array}{l}9 \text { months } \\
\text { no } \\
\text { no }\end{array}$ & $\begin{array}{l}\text { Victimization } \\
\text { bullying, self- } \\
\text { efficacy, well- } \\
\text { being at school, } \\
\text { empathy toward } \\
\text { victims, anxiety, } \\
\text { depression, peer } \\
\text { group percep- } \\
\text { tion, } \\
\text { cyber-bullying, } \\
\text { cyber- } \\
\text { victimization }\end{array}$ & High efficacy & 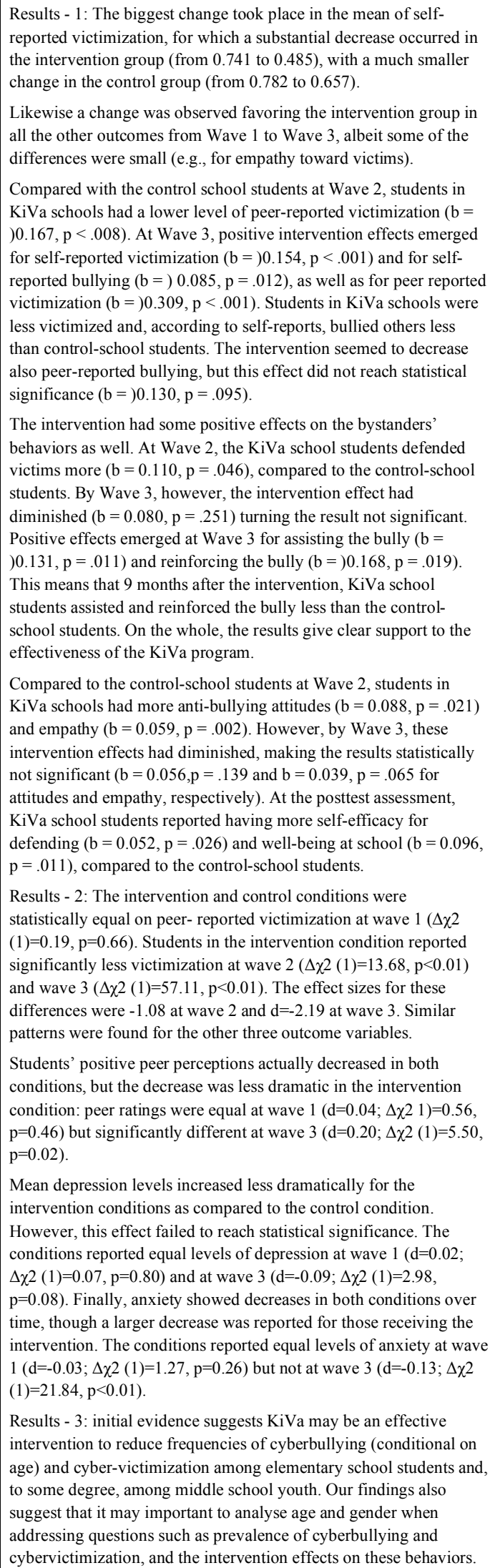 \\
\hline
\end{tabular}


(Table 4) contd....

\begin{tabular}{|c|c|c|c|c|c|c|}
\hline Authors & Program & $\begin{array}{l}\text { Duration of } \\
\text { Intervention }\end{array}$ & Follow-up & Main Effects & Efficacy & Results \\
\hline $\begin{array}{l}\text { Twemlow et al. } \\
2005\end{array}$ & $\begin{array}{l}\text { The Paceful } \\
\text { schools experi- } \\
\text { ment }\end{array}$ & Two-year trial & one year & $\begin{array}{l}\text { Aggression, } \\
\text { victimization, } \\
\text { aggressive } \\
\text { bystanding }\end{array}$ & High efficacy & $\begin{array}{l}\text { The experimental intervention showed a decrease in peer-reported } \\
\text { victimization }(\mathrm{p}<.01) \text {, aggression }(\mathrm{p}<.05) \text {, and aggressive by- } \\
\text { standing }(\mathrm{p}<.05) \text { compared to control schools. } \\
\text { The intervention showed less of a decline in empathy compared to } \\
\text { psychiatric consultation }(\mathrm{p}<.01) \text { and control conditions }(\mathrm{p}<.01) \text {. } \\
\text { The Peaceful Schools approach produced a significant decrease in } \\
\text { off-task behavior ( } \mathrm{p}<.001) \text { and disruptive classroom behavior ( } \mathrm{p} \\
<.001) \text { whereas behavioral change was not observed in the psychiat- } \\
\text { ric consultation and control schools. The findings of reduced vic- } \\
\text { timization ( }<<.05) \text {, aggression ( }<<.01) \text {, and aggressive by standing } \\
(\mathrm{p}<.01) \text { were maintained in the follow-up year. }\end{array}$ \\
\hline
\end{tabular}

The limits set by "*” are described in detail in the results paragraph.

Table 5. Problematic areas and wellbeing dimension (secondary outcomes of review).

\begin{tabular}{|c|c|c|c|}
\hline Bullying; verbal, physical and direct aggression & 15 & $\begin{array}{l}\text { Satisfaction with school life and peer relationship; peer } \\
\text { perception }\end{array}$ & 5 \\
\hline Bully Victimization; peer rejection & 7 & Mentalizing behavior; Empathy toward victims & 4 \\
\hline Cyberbullying & 1 & Self-esteem; self-efficacy & 3 \\
\hline $\begin{array}{l}\text { Antisocial affiliation; } \\
\text { Disruptive behaviors; } \\
\text { prevalence of substance use; } \\
\text { disciplinary referrals and suspensions; off task behaviors }\end{array}$ & $\begin{array}{l}1 \\
4 \\
3\end{array}$ & & \\
\hline
\end{tabular}

The KiVa program is rooted on the evidence that bullying behavior can be reduced by reducing the motivation related to the social rewards that the bully obtains from the behavior of bystanders; therefore a positive change in the behaviors of bystanders is expected to have a direct impact on the behavior of bullies $[28,6]$. The intervention on bystanders' behavior involves increasing their sense of selfefficacy regarding their ability to stop bullying behaviors, and promoting their empathy toward the victims, since both characteristics showed a correlation with the support and protection of victimized peers [43-45]. The program consists of both universal and focused actions, including classroombased lessons and between-lesson activities (such as a computer game to develop the abilities related to the lessons), as well as actions related to specific bullying incidents, through both adult and peer support for the victim, individual and group discussions with both the victim and the bully, and the identification - by the teacher - of some of the victim's classmates who were challenged to find ways to support their classmate in case of future incidents (see Salmivalli \& Poskiparta [46] for an extensive program description).
The results of the studies demonstrate the efficacy of the KiVa program in reducing the levels of bullying and victimization, and at the same time reducing several internalized symptoms related to the effect of living in a social environment perceived as unsafe, such as anxiety and depression. The KiVa program appears effective in the reduction of cyber-bullying and cyber-victimization too [30], especially when applied with younger children.

The "Youth Matters" program [47] is rooted in the theoretical framework outlined in the social development model (SDM) [48]. The SDM includes concepts coming from social control theory [49], social learning theory [50], and differential association theory [51, 52]. According to the SDM theory, four factors inhibit the development of antisocial behaviors in children: bonding, defined as attachment and commitment to the referred group (family, school) [53]; belief in the norms and values shared by the group; external constraints expressed through clear and consistent policies and standards opposing antisocial behaviors [54-56]; social, cognitive and emotional skills that give children a set of 
tools to solve problems $[57,58]$, to act with confidence and assertiveness in social situations [59], and to resist influences or impulses that may lead the subjects to violate social interaction rules [60]. This program is also the only systemic project performing the expected intervention actions at the classroom level, excluding other levels. Results yielded limited evidence of the program's positive impact on bullying behavior and, consequently, on outcome for bully victimization, which was significantly lower in the intervention group than in the control condition.

\section{Mixed Intervention Programs}

Some studies were aimed at the integration and comparison of universal interventions and at more focused actions with the children directly involved in the phenomenon [26]; or still were attempts to check the usefulness of actions involving families [61].

Fonagy [26] conducted a study to verify if the global intervention called "Creating a Peaceful School Learning Environment" (CAPSALE) obtained better effects on bullying, victimization or bystanders behavior when compared to school psychiatric consultation (SPC) provided to children (especially victims) involved in bullying episodes [26]. Fonagy found greater effects in the CAPSALE program, while the results of the individual intervention were less clear.

Malti verified the opportunity of integrating a global program, "Promoting Alternative Thinking Strategies" (PATHS), within a program addressed to the families, "Triple-P". The authors observed that the combination of the programs does not show better results than the PATH program alone, while when compared to the control group both show efficacy in improving social skills and reducing internalized and externalized problems related to violent behaviors among peers.

\section{DISCUSSION}

The phenomenon of bullying is a major problem in schools, and it originates persistent psychological problems. For the time being, there is no internationally recognized definition of bullying that takes into account all the aspects involved: bullying remains a complex, multidimensional phenomenon, whose etiology has not been identified with certainty. In a recent work [62] has highlighted a number of disputes about the definition and measurement of bullying, emphasizing the importance of distinguishing between bullying actions and aggression in general, and between victimization due to bullying and general victimization. Different models of explanation of the phenomenon are still being considered by various scientific disciplines - medical, psychological, and social sciences [63,35].

Correspondingly, bullying is of interest to researchers and clinicians and a variety of intervention models has been proposed to reduce or prevent it. Some of these programs have focused interventions directly on the students involved (i.e., the bully/cyberbully, the victims and the bystanders), while others aim to change the broader social climate (e.g. whole school approaches). According to a systematic review by Vreeman, Aaron \& Carroll [19] of school-based interven- tions, some studies have shown positive effects by the Olweus Bullying Prevention Program while others have found no reductions in victimization and bullying. In addition, significant differences in outcomes have been reported for the primary and secondary school levels. However, Vreeman and collaborator [19] found that the whole school approach is more effective than individual programs. Several authors $[10,19,64]$ already worked to determine the most effective anti-bullying intervention and to provide guidelines for the treatment of this situation. Nevertheless the results collected by the studies made so far, show that there is no clear position shared by social scientists, and a wide range of models persists. Consequently, we wondered what the variables are that actually make an intervention truly effective and replicable. In a previous meta-analysis [65] on interventions against bullying has found that the large variability of experimental designs, measures, and the types of intervention make it difficult to establish certain trends. He writes that the majority of interventions is effective in changing the opinion on bullying in people, but less effective in actually changing the dynamics of bullying. To overcome some of these difficulties, we chose to evaluate only randomized controlled trials, reducing the variety of designs and increasing the quality of the data collected.

We found that most of the experiments on bullying are not a randomized controlled trial. Which may reflect problems in carrying out such interventions. However, it is important to understand how many treatments were able to reduce the principal components of bullying (bullying, victimization and bystanders behavior). In this respect, we found that the bullying behavior is the focus of 15 studies among the selected ones, while just 7 of the interventions focused on the victims of bullying, and only 1 RCT, included in the review, dealt with the issue of cyber-bullying. In 3 studies the treatment was also focused on the behavior of those who passively participate in acts of bullying (aggressive and helpful bystanders). The reduction of aggressive or frankly antisocial behaviors was the aim of 4 studies. Finally, we directed our attention to the well-being dimensions and problematic areas, always correlated to bullying. About half of the studies focused on the reduction of psychiatric symptoms, which can be further divided into internalized symptoms such as anxiety and depression and externalizing symptoms, such as aggressive, impulsive or non-aggressive conduct disorders, dealt with by eight studies and by only one, respectively. The focus on aggressive behavior is predominant in the objectives of anti-bullying interventions, whether it is defined in terms of psychiatric illness or not.

Treatments are focused on several dimensions related to well-being of children and adolescents. 5 studies considered the social well-being dimensions, such as satisfaction for life at school, or interactions with peers; 2 studies analysed the dimension of good social functioning as related to the improvement of socio-cognitive abilities or social skills. Other aspects of wellness that anti-bullying intervention programs seek to improve are related to mental health aspects, such as the capacity of mentalization of behaviors (and therefore a greater ability to avoid implementing violent behaviors as the only social interaction strategy), the ability to show empathy for the victims (4 studies), or the levels of self-esteem and self-efficacy (3 studies), as shown in Table $\mathbf{5}$. 
Many studies are based on a social approach to bullying, and consider it as a group process that involves young people, teachers and parents in a system of mutual influences. This approach has produced programs to change the public opinion about bullying behaviors and modify behavior in the social contexts where it develops, based on the assumption that this phenomenon will change if it is counteracted on several fronts.

These anti-bullying programs seem more effective than others having a different focus. The most rewarding programs appear to be those that have the whole class as the main target of intervention, often accompanied by individually focused actions, or family involvement. These interventions are in the form of lessons, role-playing and other strategies (e.g. KiVa Program) and showed promising results.

Anti-bullying programs targeted at changing the behavior of the bully or the victim, without affecting the whole social context, also show a moderate effect on reducing the principal components of the phenomenon (primary outcomes).

As described in table 4 , about $80 \%$ of the studies reported improvements in the experimental group in at least one of the main components, which reported victimization commitment, bullying acts, or observers' attitude. This finding is encouraging, although no information is available on the duration of the effects 12 to 24 months after the treatment, and many studies did not report follow-up information.

We noted several obstacles to the generalizability of the results for each intervention program analyzed. For example, some programs showing a high reduction of bullying record poorer results if replicated in a different school district [34].

Some studies showed how the phenomenon of bullying has a natural development curve over time, but others showed a rising trend of bullying behaviors in the passage from primary to secondary school, with a higher risk of victimization and social exclusion for the victims [39]. Hence, it seems that implementing the interventions during the last grades of primary school is important to prevent the phenomenon and contributes to reducing it in the future [39]. Bullying appears to be more frequent in the male student population, which tolerates aggressive behaviors more, while among female students more indirect forms of bullying are more frequent, such as spreading rumors or social isolation. In the study by Fonagy [26], male students showed higher levels of aggressive behavior compared to females before the intervention, and at follow-up seemed to benefit from the effects of the treatment less continuously. The results of other studies though, like the KiVa program, were not affected by gender difference [28].

The socio-economic status (SES) is a variable able to predict the intensity of the presence of bullying behaviors or experiences of victimization independently from the effect of treatment [26], as it seems to be associated with the probability of experiencing bullying and/or victimization.

Previous systematic reviews on interventions against bullying have highlighted the complexity of the phenomenon [61]. The definition of bullying remains controversial and complex. Several factors such as gender, age, socioeconomic status of the young people involved in bullying are emerging as important mediators in the analysis of intervention effectiveness, and should be considered in a more systematic way to produce an operational definition of the phenomenon, and plan more timely interventions.

Some obstacles we encountered in the analysis of the studies were the variety of experimental designs and the lack standardized measures for the evaluation of the outcomes that were shared and common to different studies. This aspect makes the comparison of the studies in terms of effects and results more complex, and limits the possibility to generalize the collected information. Among the limitations was the lack of internal coherence among the measures of some studies.

Our reflections are of course affected by the many limitations of this systematic review. We only included studies published in English and, consequently, we probably excluded some relevant studies. Yet, only the studies with an RCT design were included in our analysis, and this gave a high standard in terms of quality of the designs, but at the same time led to the exclusion of a great number of antibullying intervention programs that often apply quasiexperimental or cohort study designs. In particular, this was a limitation in the selection of programs against cyberbullying: in this case we were able to include only one article. The use of variable outcome measures may further limit the ability to measure the effects of these interventions accurately.

In conclusion, the analysis presented here in should be considered as a starting point for future research. The aspects that would prove useful for the orientation of future studies include longer follow-up periods, in order to assess the actual changes over time at both the individual and the group levels; the use of validated psychometric tools; the implementation of more controlled trial studies. In order to develop a good prevention program and actions targeted at combating bullying (and cyber-bullying) and all the issues related to it (social adaptation and psychological problems), and to approach to the highest goal of school inclusion, we believe it of high importance to outline and follow a common line of action for the whole European community.

\section{CONFLICT OF INTEREST}

The authors confirm that this article content has no conflict of interest.

\section{ACKNOWLEDGEMENTS}

Declared none.

\section{REFERENCES}

[1] Due P, Holstein BE, Lynch J, et al. Bullying and symptoms among school-aged children: international comparative cross-sectional study in 28 countries. Eur J Public Health 2005; 15(2): 128-32.

[2] Olweus D. Bullying at School: what we know and what we can do. Cambridge, Mass: Blackwell Publishers Ltd 1993.

[3] Slonje R, Smith PK. Cyberbullying: another main type of bullying? Scand J Psychol 2008; 49(2): 147-54.

[4] Dooley JJ, Pyżalski J, Cross D. Cyberbullying versus face-to-face bullying. J Genet Psychol 2014; 175(5): 382-400.

[5] Menesini E, Nocentini A. Cyberbullying definition and measurement: some critical considerations. Zeitschrift fur psychologie J Psychol 2009; 217(4): 230-2. 
[6] Smith PK, Sharp S. School bullying. Insights and perspectives. London: Routledge 1994.

[7] Dake JA, Price JH, Telljohann SK. The nature and extent of bullying at school. J Sch Health 2003; 73(5): 173-80.

[8] Ttofi MM, Farrington DP. Risk and protective factors, longitudinal research, and bullying prevention. New Dir Youth Dev 2012; (133): 85-98.

[9] Arseneault L, Bowes L, Shakoor S. Bullying victimization in youths and mental health problems: 'Much ado about nothing'? Psychol Med 2010; 40(5): 717-29.

[10] Ttofi MM, Farrington DP, Lösel F, Loeber R. Do the victims of school bullies tend to become depressed later in life? A systematic review and meta-analysis of longitudinal studies, J Aggres Conf Peace Res 2011; 3: 63-73.

[11] Brown SL, Birch DA, Kancherla V. Bullying perspectives: experiences, attitudes, and recommendations of 9- to 13-year-olds attending health education centres in the United States. J Sch Health 2005; 75: 384-92.

[12] Card NA, Hodges EV. Parent-child relationships and enmity with peers: the role of avoidant and preoccupied attachment. New Dir Child Adolesc Dev 2003;(102): 23-37.

[13] Williams K, Chambers M, Logan S, Robinson D. Association of common health symptoms with bullying in primary school children. BMJ 1996; 313(7048): 17-9.

[14] Olweus D. Bullying at school: basic facts and an effective intervention programme. Promot Educ 1994; 1(4): 27-31.

[15] Dake JA, Price JH, Murnan J, Telljohann SK. Elementary school secretaries' experiences and perceptions of administering prescription medication. J Sch Health 2003; 73(10): 373-9.

[16] Kaltiala-Heino R, Rimpelä M, Marttunen M, Rimpelä A, Rantanen P. Bullying, depression, and suicidal ideation in Finnish adolescents: school survey. BMJ 1999; 319(7206): 348-5.

[17] Gini G, Pozzoli T. Bullied children and psychosomatic problems: a meta-analysis. Pediatrics 2013; 132(4): 720-9.

[18] Kochenderfer BJ, Ladd GW. Peer victimization: cause or consequence of school maladjustment? Child Dev 1996; 67(4):1305-17.

[19] Vreeman RC, Aaron E, Carroll MD. A systematic review of school-based interventions to prevent bullying. Arch Pediatr Adolesc Med 2007; 161(1): 78-88.

[20] Sancassiani F, Pintus E, Holte A, et al. Enhancing youths' emotional and social skills to promote their wellbeing and positive development: a systematic review of universal school-based randomized controlled trials. Clin Pract Epidem Mental Health 2015; 11: 21-40.

[21] Mura G, Rocha NBF, Helmich I, et al. Physical activity interventions in schools for improving lifestyle in European countries. Clin Pract Epidem Mental Health 2015; 11: 77-101.

[22] Cossu G, Cantone E, Pintus $\mathrm{M}$, et al. Integrating children with psychiatric problems in the classroom. A systematic review. Clin Pract Epidem Mental Health 2015; 11: 41-57.

[23] DeRosier ME. Building relationships and combating bullying: effectiveness of a school-based social skills group intervention. J Clin Child Adolesc Psychol 2004; 33(1): 196-201.

[24] Berry K, Hunt CJ. Evaluation of an intervention program for anxious adolescent boys who are bullied at school. J Adolesc Health 2009; 45(4): 376-82.

[25] Fekkes M, Pijpers, FI, Verloove-Vanhorick, SP. Effects of antibullying school program on bullying and health complaints. Arch Pediatr Adolesc Med 2006; 160(6): 638-44.

[26] Fonagy P, Twemlow SW, Vernberg EM, et al. A cluster randomized controlled trial of child-focused psychiatric consultation and a school systems-focused intervention to reduce aggression. J Child Psychol Psychiatry 2009; 50(5): 607-16.

[27] Li KK, Washburn I, DuBois DL, et al. Effects of the positive action program on problem behaviors in elementary school students: a matched-pair randomized control trial in Chicago. Psychol Health 2001; 26(2): 187-204.

[28] Kärnä A, Voeten M, Little TD, Poskiparta, E, Kaljonen A, Salmivalli C. A large-scale evaluation of the KiVa antibullying program: grades 4-6. Child Dev 2011; 82(1): 311-30.

[29] Williford A, Boulton A, Noland B, Little TD, Kärnä A, Salmivalli C. Effects of the KiVa anti-bullying program on adolescents' depression, anxiety, and perception of peers. J Abnorm Child Psychol 2012; 40(2): 289-300.

[30] Williford A, Elledge LC, Boulton, AJ, DePaolis KJ, Little TD, Salmivalli C. Effects of the KiVa antibullying program on cyber- bullying and cybervictimization frequency among Finnish youth. J Clin Child Adolesc Psychol 2013; 42(6): 820-33.

[31] Lewis KM, Schure MB, Bavarian N, et al. Problem behavior and urban, low-income youth: a randomized controlled trial of positive action in Chicago. Am J Prev Med 2013; 44(6): 622-30.

[32] Cross D, Monks H, Hall M et al. Three-year results of the Friendly Schools whole-of-school intervention on children's bullying behav. Br Educ Research J 2010; 37(1): 105-29.

[33] Sugai G, Horner RH. The evolution of discipline practices: schoolwide positive behavior supports. Child Family Behav Therapy 2002; $24: 23-50$.

[34] Stevens V, De Bourdeaudhuij I, Van Oost P. Bullying in Flemish schools: an evaluation of anti-bullying intervention in primary and secondary schools. Br J Educ Psychol 2000; 70(Pt 2): 195-210.

[35] Twemlow SW, Fonagy P, Sacco FC. A developmental approach to mentalizing communities: II. The Peaceful Schools experiment. Bull Menninger Clin 2005; 69(4): 282-304.

[36] Olweus D. Bullying at School: Knowledge Base and an effective Intervention Program. Annals of the New York Acad Sc 1996; 794, 265-76.

[37] Olweus D. Bullying among schoolchildren: intervention and prevention. In Peters R D V, McMahon RJ, Quinsey VL, Eds. Aggression and violence throughout the life span. Sage Publications: Newbury Park 1992: pp. 100-25.

[38] Stevens V, Van OP. Pesten op School: een Actieprogramma. Garant Uitgevers: Kessel-Lo 1994.

[39] Waasdorp TE, Bradshaw CP, Leaf PJ. The impact of school wide positive behavioural interventions and supports on bullying and peer rejection: a randomized controlled effectiveness trial. Arch Pediatr Adolesc Med. 2012; 166(2): 149-56.

[40] Seattle WA. Steps to respect: a bullying prevention program. Committee for children 2001.

[41] Brown EC, Low S, Smith BH, Haggerty KP. Outcomes from a school-randomized controlled trial of steps to respect: a bullying prevention program. School Psychol Rev 2011; 40(3), 423-43.

[42] Frey KS, Hirschstein MK, Snell JL, Edstrom LV, MacKenzie EP, Broderick CJ. Reducing playground bullying and supporting beliefs: an experimental trial of the steps to respect program. Dev Psychol 2005; 41(3): 479-90.

[43] Caravita S, DiBlasio P, Salmivalli C. Unique and interactive effects of empathy and social status on involvement in bullying. Soc dev 2009; 18: 140-63.

[44] Po"yho"nen V, Juvonen, J, Salmivalli C. What does it take to stand up for the victim of bullying? The interplay between personal and social factors. Merrill Palmer Q 2010; 56: 143-63.

[45] Salmivalli C, Voeten M. Connections between attitudes, group norms, and behaviors associated with bullying in schools. Int J Behav Dev 2004; 28: 246-58

[46] Salmivalli C, Poskiparta EM. Making bullying prevention a priority in Finnish schools: the KiVa antibullying program. New Dir Youth Dev 2012; (133): 41-53.

[47] Jenson JM, Dieterich WA. Effects of a skills-based prevention program on bullying and bully victimization among elementary school children. Prev Sci 2007; 8(4): 285-96.

[48] Catalano RF, Hawkins JD. The social development model: a theory of antisocial behavior. In: Hawkins JD, Eds. Delinquency and crime: current theories. New York: Cambridge University Press 1996; 149-97.

[49] Hirschi T. Causes of delinquency. Berkeley, CA: University of California press 1969.

[50] Bandura A. Human agency in social cognitive theory. Am Psychol 1989; 44(9): 1175-84.

[51] Matsueda RL. Testing control theory and differential association: a causal modeling approach. Am Soc Review 1982; 47: 489-504.

[52] Sutherland EH. Development of the theory [Private paper published posthumously]. In: K. Schuessler, Eds. Edwin Sutherland on analyzing crime. Chicago: University of Chicago Press 1973.

[53] Garmezy N. Stress-resistant children: The search for protective factors. In: Stevenson JE, Eds. Recent research in developmental psychopathology [Book supplement]. J child psych and psych 1985; 4: 213-33.

[54] Hansen WB, Malotte CK, Fileding JE. Evaluation of a tobacco and alcohol abuse prevention curriculum for adolescents. Special Issue: The role of the schools in implementing the nation's health objectives for the 1990's. Health Educ Q 1988; 15: 93-114. 
[55] Scheier LM, Botvin GJ. Relations of social skills, personal competence, and adolescent drug use: A developmental exploratory study. J Early Adol 1998; 18: 77-114.

[56] Werner EE. High-risk children in young adulthood: A longitudinal study from birth to 32 years. Am J Orthopsychiatr 1989; 59: 72-81.

[57] Anthony EJ. Risk, vulnerability, and resistance. In: EJ Anthony, BJ Choler, Eds. The invulnerable. New York: Guilford press 1987: pp. $3-48$.

[58] Rutter M. Resilience in the face of adversity: protective factors and resistance to psychiatric disorder. Br J Psychiatry 1985; 147: 598611.

[59] Werner E, Smith RS. Vulnerable but invincible: a longitudinal study of resilient children and youth. New York: Adams, Bannister, and Cox 1982.

[60] Hansen WB, Graham JW, Sobel JL, Shelton DR, Flay BR, Johnson $\mathrm{CA}$. The consistency of peer and parent influences on tobacco, al- cohol, and marijuana use among young adolescents. J Behav Med 1987; 10(6): 559-79.

[61] Malti T, Ribeau D, Eisner MP. The effectiveness of two universal preventive intervention in reducing children's externalizing behavior: a cluster randomized controlled trial. J Clin Child Adolesc Psychol 2011; 40(5): 677-92.

[62] Olweus D. School bullying: development and some important challenges. Annual Rev Clin Psychol 2013; 9: 751-80.

[63] Singer JD. Using SAS proc mixed to fit multilevel, hierarchical models and individual growth models. J Educ Beahav Statistic 1998; 24: 323-55.

[64] Smith PK, Ananiadou K. The nature of school bullying and the effectiveness of school-based interventions. J Applied Psychoanalytic St 2003; 5(2): 189.

[65] Merrell KW, Gueldner BA, Ross WS. How Effective Are School Bullying Intervention Programs? A Meta-Analysis of Intervention Research. Sch Psych Q 2008; 23(1): 26-42.

(c) Cantone et al.; Licensee Bentham Open.

This is an open access article licensed under the terms of the Creative Commons Attribution Non-Commercial License (http://creativecommons.org/licenses/by-nc/3.0/) which permits unrestricted, non-commercial use, distribution and reproduction in any medium, provided the work is properly cited. 